\title{
ВЛИВ КОМБІНОВАНОЇ ДІЇ КАРАГІНАНУ ТА НАТРІЮ ГЛУТАМАТУ НА ПОКАЗНИКИ ГЕМОПОЕЗУ
}

Влив комбінованої дії карагінану та натрію глутамату на показники гемопоезу

\section{П. І. Бучко, М. І. Марущак}

Тернопільський національний медичний університет імені І. Я. Горбачевського МОЗ України

Резюме. Незважаючи на велику кількість наукових доказів щодо підтримки безпеки застосування натрію глутамату і карагінану, деякі дослідники стверджують про упередженість даних про безпеку їх застосування, що створює передумови для глибшого вивчення їх комбінованого впливу в умовах експерименту.

Мета дослідження - проаналізувати показники гемопоезу в тварин за умови експериментального застосування розчину карагінану, натрію глутамату та їх комбінованого впливу.

Матеріали і методи. Дослідження проведено на 48 білих нелінійних самцях-щурах, яких поділили на 4 групи: перша - контрольна (інтактні тварини), друга тварини, яким внутрішньошлунково вводили карагінан у дозі 40 мг/кг протягом 1 місяця; третя група - щури, яким внутрішньошлунково вводили натрію глутамат в дозі 50 мг/кг протягом 1 місяця; четверта група тварини, яким внутрішньошлунково вводили карагінан і натрію глутамат у вищевказаних дозах. Підрахунок кількості еритроцитів здійснювали за допомогою мікроскопа в лічильних камерах із сіткою Горяєва, визначення гемоглобіну крові - геміглобінцианідним методом. Для підрахунку ретикулоцитів в 0,3 мл крові додавали 100 мкл 1\% барвника діамантового крезилового блакитного, підрахунок проводили за допомогою мікроскопа. Концентрацію еритропоетину (ЕПО) визначали імуноферментним методом.

Результати. При дослідженні показників червоної крові та концентрації ЕПО у тварин першої і другої дослідних груп патологічних змін не відмічалось. Встановлено, що рівень гемоглобіну крові усіх дослідних груп вірогідно різнився при проведенні аналізу рангових варіацій Крускала - Уолісса. При цьому в тварин, яким застосовували комбіноване введення карагінану і натрію глутамату, були вірогідно нижчі показники кількості еритроцитів та гемоглобіну щодо першої і другої дослідних груп, так і контрольної. Концентрація ЕПО в третій дослідній групі перевищувала значення даного показника як в контрольній (на 32,05 \%), так і в першій (на 34,64 \%) та другій (на 32,61 \%) дослідних групах.

Висновки. Комбіноване застосування розчину к-карагінану та натрію глутамату має негативний (с). І. Бучко, М. І. Марущак, 2020
Influence of the carrageenan and sodium glutamate combined action on hemopoesis indicies

\section{P. I. Buchko, M. I. Marushchak}

I. Horbachevsky Ternopil National Medical University e-mail: marushchak@tdmu.edu.ua

Summary. Despite the large number of scientific indicators to support the safety of glutamate sodium and carrageenan, some researchers provide preliminary information on the safety of their use, which creates the preconditions for an in-depth study of their combined effects in the experimental environment.

The aim of the study - to analyze the indicies of hematopoiesis in animals in case of experimental usage of carrageenan solution, monosodium glutamate and their combined effect.

Materials and Methods. The study was performed on 48 white nonlinear male rats, which were divided into 4 groups: 1 - control (intact animals), 2 - animals that were intragastrically administered carrageenan at a dose of $40 \mathrm{mg} / \mathrm{kg}$ during 1 month, 3 - animals that were intragastrically administered monosodium glutamate at a dose of $50 \mathrm{mg} / \mathrm{kg}$ during 1 month, 4 - animals that were intragastrically administered combination of carrageenan and monosodium glutamate in the same doses. The erythrocytes level is carried out with the help of a microscope in counting chambers with a Goryaev grid, determination of blood hemoglobin by hemiglobiancyanide method. To count reticulocytes in $0.3 \mathrm{ml}$ of blood, $100 \mu \mathrm{l}$ of $1 \%$ diamond cresyl blue dye was added, the count was performed using a microscope. The concentration of erythropoietin (EPO) was determined by enzyme-linked immunosorbent assay.

Results. In the study of red blood cell counts and EPO concentrations in animals of groups 1 and 2, no pathological changes was occurred. It was found that the level of hemoglobin in the blood of all studied groups was significantly different when analyzing the rank variations of Kruskal-Wallis. Prior to that, in animals, using the combined administration of carrageenan and monosodium glutamate, the number of erythrocytes and hemoglobin was significantly lower than both experimental groups 1 and 2, and the control one. The concentration of EPO in experimental group 3 exceeded the value of this indicator both in the control (32.05\%) and in experimental group 1 (34.64\%) and $2(32.61 \%)$.

Conclusions. The combined usage of $k$-carrageenan and monosodium glutamate solutions has a negative effect
ISSN 2706-6282(print) ISSN 2706-6290(online)
Вісник медичних і біологічних досліджень Bulletin of Medical and Biological Research 
вплив на гемопоез, що проявляється статистично значимим зниженням показників еритроцитів $і$ гемоглобіну та підвищенням концентрації еритропоетину.

Ключові слова: к-карагінан; натрій глутамат; комбінація; еритроцити; гемоглобін; ретикулоцити; еритропоетин.

\section{ВСТУП}

Харчові добавки широко використовуються в харчовій промисловості для збереження якості їжі, досягнення однорідності, підвищення смаку або поліпшення текстури харчового продукту [1]. Друге місце щодо споживання добавок після харчової індустрії займає косметична промисловість для виготовлення лосьйонів, кремів, шампунів [2]. Також харчові добавки використовують у текстильній промисловості, в біотехнологічному виробництві для іммобілізації клітин і як замінник бактеріологічного агару [3]. 3 розширенням виробництва харчових добавок постійно зменшується асортимент харчових й промислових продуктів, одержаних без їх використання [4].

Однією 3 найпоширеніших харчових добавок, що використовується у всьому світі, є підсилювач смаку, який називається натрію глутаматом (MSG), що є натрієвою сіллю природної L-форми глутамінової кислоти [5]. Споживання високих концентрацій MSG, за даними різних авторів, спричиняє розвиток неврологічних захворювань [6], нейроендокринних аномалій $[7,8], €$ деякі повідомлення про токсичну дію MSG на печінку та нирки [9]. Рецептори глутамату наявні в печінці, легенях, нирках, селезінці та яєчках, тому найбільш несприятливий або токсичний вплив MSG, ймовірно, буде на ці тканини $[10,11]$.

Серед харчових добавок добре відомі також полісахариди, що мають високу молекулярну масу, добре розчиняються у воді й використовуються для поліпшення текстури кінцевої продукції $[12$, 13]. Відомо, що карагінани є потужними індукторами запалення, а ступінь токсичності залежить від молекулярної маси біополімера і кількості залишків сірчаної кислоти $[14,15]$.

Незважаючи на велику кількість наукових доказів щодо підтримки безпеки застосування натрію глутамату і карагінану, деякі дослідники стверджують про упередженість даних щодо безпеки їх застосування, і створює передумови для глибшого вивчення їх комбінованого впливу в умовах експерименту.

Метою дослідження було проаналізувати показники гемопоезу в тварин за умови експериментального застосування розчину карагінану, натрію глутамату та їх комбінованого впливу. on hematopoiesis, which is manifested by a statistically significant decrease in erythrocytes and hemoglobin levels and an increase in the concentration of erythropoietin.

Key words: K-carrageenan; monosodium glutamate; combination; erythrocytes; hemoglobin; reticulocytes; erythropoietin.

\section{МАТЕРІАЛИ I МЕТОДИ}

Дослідження проведено на 48 білих нелінійних самцях-щурах, яких утримували на стандартному раціоні віварію Тернопільського національного медичного університету імені І. Я. Горбачевського МОЗ України. Під час роботи дотримувалися принципів Європейської конвенції із захисту лабораторних тварин. Дослідних щурів поділили на 4 групи: перша - контрольна (інтактні тварини), друга - тварини, яким внутрішньошлунково вводили карагінан у дозі 40 мг/кг, розчинений в 0,5 мл дистильованої води кімнатної температури, протягом 1 місяця [16, 17]; третя група - щури, яким внутрішньошлунково вводили натрію глутамат в дозі $50 \mathrm{мг/кг,} \mathrm{розчинений} \mathrm{в} \mathrm{0,5} \mathrm{мл} \mathrm{дистильованої} \mathrm{води}$ кімнатної температури, протягом 1 місяця [18]; четверта група - тварини, яким внутрішньошлунково вводили карагінан і натрію глутамат у вищевказаних дозах.

Підрахунок кількості еритроцитів здійснювали за допомогою мікроскопа в лічильних камерах із сіткою Горяєва, визначення гемоглобіну крові - геміглобінцианідним методом. Для підрахунку ретикулоцитів в 0,3 мл крові додавали 100 мкл 1\% барвника діамантового крезилового блакитного, пошук і підрахунок проводили в 1000 еритроцитів за допомогою мікроскопа. Концентрацію еритропоетину (ЕПО) визначали імуноферментним методом за допомогою набору реагентів «Rat Erythropoietin ELISA (RAB1897-1KT)» (Sigma Aldrich).

Статистичну обробку цисрових даних здіснювали за допомогою програмного забезпечення Excel (Microsoft, США) i STATISTICA 6.0 (Statsoft, США). У випадку непараметричного розподілу кількісні характеристики ознак представляли у вигляді медіани та квартилів (першого і третього) $\operatorname{Me}\left(Q_{25} ; Q_{75}\right)$.

\section{РЕЗУЛЬТАТИ Й ОБГОВОРЕННЯ}

При дослідженні показників червоної крові та концентрації ЕПО у тварин першої і другої дослідних груп патологічних змін не відмічалось. Встановлено, що рівень гемоглобіну крові усіх дослідних груп вірогідно різнився при проведенні аналізу рангових варіацій Крускала - Уолісса (табл.). При цьому в щурів, яким застосовували комбіноване введення карагінану і натрію глутамату, були вірогідно нижчі показники кількості еритроцитів та 
гемоглобіну щодо першої і другої дослідних груп, так і контрольної. Концентрація ЕПО в третій дослідній групі перевищувала значення даного показника як в контрольній (на 32,05 \%), так і в першій (на 34,64 \%) та другій (на 32,61 \%) дослідних групах (табл.).

Отримані результати A. N. A. AL-Sharkawy et al. [5] продемонстрували зниження еритроцитів та рівня гемоглобіну в крові щурів за умови застосування натрію глутамату. Результати іншого дослідження показали, що споживання MSG та рівень гемоглобіну позитивно пов'язані між собою через життєво важливу роль лептину в кровотворенні людини. Sharma et al. вказують на те, що а-кетоглутаратдегідрогеназа, рецептори глутамату та антиспортери цистеїн-глутамату відіграють потенційну роль у регуляції окиснювального стресу при токсичності, яку зумовив MSG [19]. Результати Ashaolu et al. [20] та Ibrahim et al. [21] вказують на опосередкований негативний вплив MSG на гемопоетичні стовбурові клітини в кістковому мозку. 3 іншого боку, MSG може зумовлювати оксидативний стрес, який зумовлює утворення мікроядерних поліхроматичних еритроцитів [22]. Дослідження карагінану також показали активацію пероксидного окиснення ліпідів як у стінці тонкої кишки, так і в тканинах печінки та міокарда, що веде до тканинної гіпоксії [12]. Комбінована дія досліджуваних харчових добавок може сумувати токсичний еорект кожної добавки, що проявляється зниженням рівня еритроцитів і гемоглобіну та підвищенням концентрації ЕПО. Процес еритропоезу регулюється еритропоетином за принципом негативного зворотного зв'язку. Гіпоксія викликає посилення продукції еритропоетину нирками. Він циркулює в плазмі й зв'язується в кістковому мозку з клітинами - попередниками еритроцитів. У результаті підвищується їх життєздатність, блокується процес апоптозу, стимулюється проліферація і диференціація, що й призводить до збільшення кількості еритроцитів. Це викликає, у свою чергу, посилення оксигенації крові та зниження виділення еритропоетину.

Таблиця. Показники еритропоезу при комбінованій дії харчових добавок

\begin{tabular}{|c|c|c|c|c|}
\hline Показник & $\begin{array}{l}\text { Еритроцити, } \\
\times 10^{12} / л\end{array}$ & Гемоглобін, г/л & $\begin{array}{c}\text { Ретикуло- } \\
\text { цити (абс. } \\
\text { значення), } \\
\text { ×1012/л }\end{array}$ & $\begin{array}{l}\text { Еритропоетин, } \\
\text { пг/мл }\end{array}$ \\
\hline Контрольна & $6,86(6,75 ; 7,10)$ & $149,00(147,50 ; 152,70)$ & $\begin{array}{c}0,007 \\
(0,06 ; 0,07)\end{array}$ & $\begin{array}{c}23,40 \\
(22,75 ; 23,90)\end{array}$ \\
\hline Перша група (карагінан) & $6,94(6,78 ; 7,13)$ & $149,50(148,00 ; 152,00)$ & $\begin{array}{c}0,007 \\
(0,06 ; 0,07)\end{array}$ & $\begin{array}{c}22,95 \\
(22,45 ; 23,98)\end{array}$ \\
\hline Друга група (натрію глутамат) & $6,85(6,75 ; 7,03)$ & $149,00(146,00 ; 152,00)$ & $\begin{array}{c}0,007 \\
(0,06 ; 0,07)\end{array}$ & $\begin{array}{c}23,30 \\
(22,80 ; 23,60)\end{array}$ \\
\hline $\begin{array}{l}\text { Третя група (карагінан+натрію } \\
\text { глутамат) }\end{array}$ & $5,85^{\star}(5,75 ; 6,15)$ & $140,00 *(138,75 ; 142,00)$ & $\begin{array}{c}0,007 \\
(0,06 ; 0,07)\end{array}$ & $\begin{array}{c}30,90^{\star} \\
(29,25 ; 32,35)\end{array}$ \\
\hline Критерій Краскела -Уолліса, p & $\mathrm{H}=4,47 ; p>0,05$ & $H=21,10 ; p<0,001^{*}$ & $\begin{array}{l}H=0,16 \\
p>0,05\end{array}$ & $\mathrm{H}=2,44 ; p>0,05$ \\
\hline
\end{tabular}

Примітки: 1) * - статистично значущі результати;

2)^ - вірогідність відмінностей між третьою та іншими групами.

Висновки. Комбіноване застосування розчину к-карагінану та натрію глутамату має негативний вплив на гемопоез, що проявляється статистично

\section{СПИСОК ЛІТЕРАТУРИ}

1. Mahindru S. N. Food additives: Characteristics, detection and estimation. McGraw-Hill, New Delhi; 2004.

2. Carrageenans-sulfated polysaccharides from red seaweeds as matrices for the inclusion of echinochrome / I. M. Yermak, N. P. Mischchenko, V. N. Davydova [et al.] // Mar. Drugs. - 2017. - No.15 (11). - P. 337

3. Structural characteristics of carrageenan gels: Temperature and concentrations dependence / Y. Yuguchi, T. T. T. Thuy, H. Urakawa [et al.] // Food Hydrocolloids. 2002. - No. 16 (6). - P. 515-522.

4. List of substances scheduled for evaluation and request for data. 85th JECFA. - 2017. значимим зниженням показників еритроцитів і гемоглобіну та підвищенням концентрації еритропоетину.

5. Pathological study on the effect of some food additives in male albino rats / A. N. A. AL-Sharkawy, M. S. Gab-Allah, A. B. I. El-Mashad [et al.] // Benha Veterinary Medical Journal. - 2017. - No. 33 (2). - P. 75-87.

6. Simple and inexpensive flow L-glutamate determination using pumpkin tissue / N. J. Arruda, J. L. Filho, M. C. Montenegro [et al.] // J. Agric. Food Chem. - 2003. No. 51 (24). - P. 6945-6948.

7. Orexin a stimulates hypothalamic-pituitary-adrenal (HPA) axis function, but not food intake, in the absence of full hypothalamic NPY-ergic activity / G. Moreno, M. Perello, R. C. Gaillardand [et al.]//Endocrine. -2005. -No. 26. - P. 99-106. 
8. Аналіз потенціалу системи глутатіону в щурів 3 аліментарним ожирінням / М. І. Марущак, О. П. Мялюк, У. П. Гевко [та ін.] // Медична та клінічна хімія. - 2017. № 19 (2). - C. 60-65.

9. A comparative study on the effects of excessive consumption of ginger, clove, red pepper and black pepper on the histology of the kidney / A. O. Nwaopara, M. A. C. Odike, U. Inegbenebor [et al.] // Pak. J. Nutr. - 2008. - No. 7. - P. 287-291.

10. Soliman A. M. Extract of coelatura aegyptiaca, a freshwater clam, ameliorates hepatic oxidative stress induced by monosodium glutamate in rats / A. M. Soliman // African Journal of Pharmacy and Pharmacology. - 2011. No. 5 (3). - P. 398-408.

11. The toxic impact of monosodium glutamate in rats / I. Krynytska, M. Marushchak, L. Naumova [et al.] // Jordan Medical Journal. - 2019. - No. 53 (2). - P. 91-101.

12. Kopanytsia O. M. Metabolic processes in the small intestine wall, heart and liver in experimental intake of carrageenan / O. M. Kopanytsia, M. I. Marushchak, A. A. Shcherbatyy // Medical and Clinical Chemistry. - 2017. - No. 3. P. 108-113.

13. The indices of endogenous intoxication in rats with carrageenan solution consumption / I. Krynytska, M. Marushchak, O. Svan [et al.] // Georgian Medical News. - 2018. - No. 279. - P. 196-200.

14. Tobacman J. K. The common food additive carrageenan and the alpha-gal epitope. J. Allergy Clin. Immunol. - 2015. - No. 136 (6). - P. 1708-1709.

15. Johari N. S. C. Efficacy study of carrageenan as an alternative infused material (filler) in poly (3-hydroxybutyrate-co-3-hydroxyvalerate) Porous 3D Scaffold / N. S. C. Johari, S. Aizad, S. I. Zubairi // International Journal of Polymer Science. - 2017.

\section{REFERENCES}

1. Mahindru SN. Food additives: Characteristics, detection and estimation, McGraw-Hill, New Delhi. 2004.

2. Yermak IM, Mischchenko NP, Davydova VN, Glazunov VP, Tarbeeva DV, Kravchenko AO, Pimenova EA, et al. Carrageenans-sulfated polysaccharides from red seaweeds as matrices for the inclusion of echinochrome. Mar Drugs. 2017;15(11): 337.

3. Yuguchi Y, Thuy TTT, Urakawa H, Kajiwara K. Structural characteristics of carrageenan gels: Temperature and concentrations dependence. Food Hydrocolloids. 2002;16(6): 515-22.

4. List of substances scheduled for evaluation and request for data. 85th JECFA. 2017.

5. AL-Sharkawy ANA, Gab-Allah MS, El-Mashad ABI, Khater DF. Pathological study on the effect of some food additives in male albino rats. Benha Veterinary Medical Journal. 2017;33(2): 75-87.

6. Arruda NJ, Filho JL, Montenegro MC, Arau'jo AN, Silva VL. Simple and inexpensive flow L-glutamate determination using pumpkin tissue. J Agricul and Food Chemistry. 2003;51: 6945-8.

7. Moreno G, Perello M, Gaillardand RC, Spine E. Orexin astimulates hypothalamic-pituitv-adrenal (HPA) axis function, but not food intake in the absence of full hypothalamic NPY- ergic activity. Endocrine. 2005;26: 99-106.

8. Marushchak MI, Myalyuk OP, Gevko UP, Gabor GG,
16. Пат. 97322 Україна, МПК G09B 23/28. Спосіб моделювання хронічного гастроентероколіту / Іваненко Т. О., Коробчанський В. О., Губіна-Вакулик Г. І., Горбач Т. В., Колоусова Н. Г; № а201014510; заявл. 06.12.2010; опубл. 25.01.2012, Бюл. № 2.

17. Moyana T. N. Carrageenan-induced intestinal injury in the rat - a model for inflammatory bowel disease I T. N. Moyana, J. M. Lalonde // Ann. Clin. Lab. Sci. - 1990. No. 20 (6). - P. 420-426.

18. Влияние глипролинов на структурно-срункциональное состояние слизистой оболочки желудка и массу тела крыс в условиях длительного введения глутамата натрия / Т. М. Фалалеева, Г. Е. Самонина, Т. В. Береговая [и др.] // Фізика живого. - 2010. - № 18 (1). - C. 154-159

19. Monosodium glutamate intake increases hemoglobin level over 5 years among Chinese adults / Z. Shi, B. Yuan, A. W. Taylor [et al.] // Amino Acids. - 2012. No. 43. - P. 1389-1397.

20. Effect of monosodium glutamate on hematological parameters in Wistar rats / J. O. Ashaolu, V. O. Ukwenya, A. B. Okonoboh [et al.] // International Journal of Medicine and Medical Sciences. - 2011. - No. 3 (6). - P. 219-222.

21. Ibrahim O. M. S. Some hematological and histological impact of sub-acute exposure to mono sodium glutamate in mice / O. M. S. Ibrahim, N. N. Abdulhamza, $\mathrm{H}$. K. Abbass // Proceeding of the Eleventh Veterinary Scientific Conference. - 2012. - P. 127-131.

22. Farmobi E. O. Monosodium glutamate-induced oxidative damage and genotoxicity in the rat: Modulatory role of vitamin C, vitamin E and quercetin / E. O. Farmobi, O. O. Onyema // Hum. Exp. Toxicol. - 2006. - No. 25. P. 251-259.

Yaroshenko TYa, Antonyshyn IV. [Analysis of the potential of the glutathione system in rats with alimentary obesity]. Medychna ta klinichna khimiia. 2017;19(2): 60-5. Ukrainian.

9. Nwaopara AO, Odike MAC, Inegbenebor U, Nwaopara SO, Ewere GI. A comparative study on the effects of excessive consumption of ginger, clove, red pepper and black pepper on the histology of the Kidney. Pak J Nutr. 2008;7: 287-91.

10. Soliman AM. Extract of coelatura aegyptiaca, a freshwater clam, ameliorates hepatic oxidative stress induced by monosodium glutamate in rats. African $\mathrm{J}$ of Pharmacy and Pharmacology. 2010;5(3): 398-408.

11. Krynytska I, Marushchak M, Naumova L, Mazur L. The toxic impact of monosodium glutamate in rats. Jordan Medical Journal. 2019;53(2): 91-101.

12. Kopanytsia OM, Marushchak MI, Shcherbatyy AA. Metabolic processes in the small intestine wall, heart and liver in experimental intake of carrageenan. Medical and Clinical Chemistry. 2017;3: 108-113.

13. Krynytska I, Marushchak M, Svan O, Akimova V, Mazur L, Habor $\mathrm{H}$. The indices of endogenous intoxication in rats with carrageenan solution consumption. Georgian Medical News. 2018;279: 196-200.

14. Tobacman JK. The common food additive carrageenan and the alpha-gal epitope. J Allergy Clin Immunol. 2015;136(6): 1708-9. 
15. Johari NSC, Aizad S, Zubairi SI. Efficacy study of carrageenan as an alternative infused material (filler) in poly (3-hydroxybutyrate-co-3-hydroxyvalerate) Porous 3D Scaffold. International Journal of Polymer Science; 2017.

16. Ivanenko TO, Korobchansky VO, Gubina-Vakulyk GI, Gorbach TV, Kolousova NG. Method of modeling chronic gastroenterocolitis: US Pat. 97322. Ukraine. 2012.

17. Moyana TN, Lalonde JM. Carrageenan-induced intestinal injury in the rat - a model for inflammatory bowel disease. Ann Clin Lab Sci. 1990;20(6): 420-6.

18. Falaleeva TM, Samonina GE, Beregovaya TV, Dzyubenko NV, Andreeva LA. [The effect of glyprolines on the structural and functional state of the gastric mucosa and body weight of rats under conditions of prolonged administration of sodium glutamate]. Fizika zhivogo. 2010;18(1): 154-9. Russian.
19. Shi Z, Yuan B, Taylor AW, Dal Grande E, Wittert GA. Monosodium glutamate intake increases hemoglobin level over 5 years among Chinese adults. Amino Acids. 2012;43: 1389-97.

20. Ashaolu JO, Ukwenya VO, Okonoboh AB, Ghazal OK, Jimoh AAG. Effect of monosodium glutamate on hematological parameters in Wistar rats. International Journal of Medicine and Medical Sciences. 2011;3(6): 219-222.

21. Ibrahim OMS, Abdulhamza NN, Abbass HK. 2012. Some hematological and histological impact of sub-acute exposure to mono sodium glutamate in mice. Proceeding of the Eleventh Veterinary Scientific Conference. 2012; 127131.

22. Farmobi EO, Onyema OO. Monosodium glutamateinduced oxidative damage and genotoxicity in the rat: Modulatory role of vitamin C, vitamin E and quercetin. Hum Exp Toxicol. 2006;25: 251-9. 